Wu, G. and Bennett, S. and Bornman, J. and Clarke, M. and Fang, Z. and Johnson, S. 2017. Phenolic profile and content of sorghum grains under different irrigation managements. Food Research International. 97: pp. 347-355.

\title{
1 Phenolic profile and content of sorghum grains under different irrigation managements
}

2 Gangcheng Wu ${ }^{1}$, Sarita J. Bennett ${ }^{2}$, Janet F. Bornman ${ }^{3}$, Michael W. Clarke ${ }^{4}$, Zhongxiang Fang ${ }^{5^{*}}$, Stuart

3 K. Johnson ${ }^{1 *}$.

$4{ }^{1}$ School of Public Health, Curtin Health Innovation Research Institute, Curtin University, Perth, WA 6845,

$5 \quad$ Australia

$6{ }^{2}$ Department of Environment and Agriculture, School of Science, Curtin University, Perth, WA 6845,

$7 \quad$ Australia

$8{ }^{3}$ International Institute of Agri-Food Security (IIAFS), Curtin University, PO Box U1987, Perth, WA 6845,

$9 \quad$ Australia

$10{ }^{4}$ Centre for Microscopy, Characterisation and Analysis - M310, Perth, WA, 6009, Australia

$11{ }^{5}$ Faculty of Veterinary and Agricultural Sciences, The University of Melbourne, Parkville, Victoria 3010,

12 Australia.

14 *Corresponding Authors:

15 Email: zhongxiang.fang@unimelb.edu.au;Tel:+61-3-83445063 (ZF);

16 Email: S.Johnson@curtin.edu.au; Tel: +61-8-9266 9486 (SKJ) 
Abstract:

Sorghum grain is widely consumed in Sub-Saharan Africa and Asia, as a staple food due to its adaptation to harsh environments. The impact of irrigation regime: full irrigation (100\%); deficit irrigation (50\%); and severe deficit irrigation (25\%) on phenolic profile and content of six sorghum grain genotypes was investigated by high performance liquid chromatography coupled with diode array detection and electrospray ionization mass spectrometry (HPLC-DAD-ESI-MS). A total of 25 individual polyphenols were unequivocally or tentatively identified. Compared to the colored-grain genotypes, the white grained sorghum var. Liberty had a simpler polyphenol profile. The concentrations of the sorghum-specific 7 3-deoxyanthocyanidins luteolinidin and apigeninidin, were higher under deficit irrigation compared to the other two regimes in all genotypes. These findings will be valuable for the selection of sorghum genotypes for grain production as human food under water deficit conditions, since polyphenol levels can affect the grain's nutritional value and health properties.

Keywords: sorghum; genotype; irrigation; polyphenols; HPLC-MS 


\section{Introduction}

Sorghum (Sorghum bicolor (L.) Moench) is the fifth most valuable global cereal crop, widely grown in semi-arid and arid regions of the world because of its tolerance to drought and high temperatures (Taylor, Schober, \& Bean, 2006). In many parts of Africa and Asia, sorghum grain provides nutrients and energy for millions of local people, whereas in the developed countries such as the USA and Australia, it is used primarily as an animal feed or for biofuel production (Stefoska-Needham, Beck, Johnson, \& Tapsell, 2015). However, the number of people consuming sorghum grain is slowly but steadily increasing in developed countries mainly due to sorghum's gluten-free property and antioxidant potential from polyphenolic phytochemicals (Taylor et al., 2006).

Polyphenols have antioxidant activity due to their free-radical scavenging capability, and thus may protect against some chronic diseases, such as coronary heart disease and type 2 diabetes (Dykes \& Rooney, 2007). Polyphenols in sorghum grain consist of simple phenolic acids (e.g. ferulic and p-coumaric acids), 3-deoxyanthocyanidins, flavanones, flavones and other flavonoids, as well as condensed tannins (Awika \& Rooney, 2004). In particular, the 3-deoxyanthocyanidins, including apigeninidins, luteolinidins, 5-methoxyluteolinidin and 7-methoxyapigeninidin, are at high levels in some sorghum grain genotypes, but are absent in other cereal grains (Awika \& Rooney, 2004; L Dykes \& Rooney, 2007). The amounts and profiles of polyphenols in sorghum grain vary significantly between genotypes. For example, it has been reported that red and yellow sorghum genotypes 
contained high amounts of flavones, and sorghum genotypes with pigmented testa have higher content of condensed tannins (Taleon, Dykes, Rooney, \& Rooney, 2014; Wu et al., 2016a).

Under a changing climate, annual mean precipitation is projected to decrease in many mid-latitude and subtropical dry regions, in which crops, such as sorghum, maize and pearl millet, will invariably suffer from moisture stress (Pachauri et al., 2014). Polyphenol content and antioxidant activity of plant materials may be affected by water deficit, and their changes depend on plant species (Cohen \& Kennedy, 2010). Tovar, Motilva, and Romero (2001) planted young olive trees under seven irrigation treatments. They found that the concentration of the dialdehydic form of elenolic acid and oleuropein aglycon of the olive oils and the antioxidant activity significantly increased as the amount of irrigation water decreased to deficit levels. Buendía, Allende, Nicolás, Alarcón, and Gil (2008) investigated the effects of regulated deficit irrigation and full irrigation on polyphenols and antioxidant activity of peaches, and reported that the content of phenolics, mainly anthocyanins and procyanidins, and antioxidants increased under regulated deficit irrigation. In another study, comparing irrigated and non-irrigated grapevines, the levels of proanthocyanidins and flavonols increased in fruit from irrigated vines (Zarrouk et al., 2012). There is little information in the literature from controlled studies investigating how level of irrigation influences profile and concentrations of polyphenols of sorghum grain. In our recent study, it was found that the levels of total polyphenol and antioxidant activity of sorghum grain significantly increased when the amount of water was reduced (Wu, 
Johnson, Bornman, Bennett, \& Fang, 2017). However, individual polyphenols of sorghum grain were not measured in the previous study, and it is also still unknown how irrigation treatment influences the profile of polyphenols in sorghum grain.

Therefore, in the present study, using an as yet unreported trial, the effects of three levels of irrigation treatments on the individual phenolic compounds of six different sorghum genotypes were determined by the powerful analytical technique of high performance liquid chromatography coupled with diode array detection and electrospray ionization mass spectrometry (HPLC-DAD-ESI-MS).

\section{Materials and methods}

\subsection{Plant material and treatments}

The sorghum field experiment was conducted at Curtin University's Field Trials Area, Western Australia (latitude $32^{\circ} 00^{\prime} \mathrm{S}$, longitude $115^{\circ} 53^{\prime} \mathrm{E}$, altitude $20 \mathrm{~m}$ ). Daily rainfall and minimum/ maximum air temperature were obtained from the Perth Airport Bureau of Meteorology weather station 9.6Km away from the experimental site (Supplementary Fig S1) (BOM, 2013).

Six sorghum genotypes comprised of two hybrid lines ('Liberty' white pericarp and 'MR Bazley’ red pericarp) and four inbred lines ('Alpha' red pericarp; 'IS1311C' and 'IS8237C' both brown pericarp; and 'Shawaya Short Black 1', dark red-black pericarp). All seeds were provided from the Australian sorghum pre-breeding program, a partnership between the University of Queensland, the Queensland Department of Agriculture and Fisheries and the Grains Research and Development Corporation, courtesy of Professor David Jordan. All samples were planted in $1 \mathrm{~m}$ x $1 \mathrm{~m}$ fibre glass 
pots with a depth of $0.5 \mathrm{~m}$. One row each of three sorghum genotypes were planted in each pot, with a row spacing of $0.25 \mathrm{~m}$. Each row was sown on 9th January 2014 with 10 seeds of the nominated variety and thinned to five plants spaced $0.2 \mathrm{~m}$ apart after two weeks. The experiment of 6 genotypes $\mathrm{x}$ three levels of irrigation was carried out in two replications with a randomised complete block design.

The potential reference crop evapotranspiration $\left(\mathrm{PET}_{0}\right)$ from the nearby weather station was $822.7 \mathrm{~mm}$ from sorghum sowing date to maturity $10^{\text {th }}$ May. In the same period, the crop potential evapotranspiration under standard conditions (PETc) was calculated from $\mathrm{PET}_{0}$ and the Food and Agricultural Organization (FAO) crop coefficient (Kc) for sorghum, giving a PETc of 576.25mm (Allen, Pereira, Raes, \& Smith, 1998). The experimental irrigation implementation was based on PETc. Three irrigation regimes were applied: full irrigation (FI, 100\% PETc), deficit irrigation (DI, $50 \%$ PETc) and severe deficit irrigation (SDI, 25\% PETc).

The sowing date was defined as 0 day after sowing, and all plants received unlimited water in the first two weeks. After that, all irrigation treatments were applied by hand watering. Sorghum was irrigated every 3-4 days with a total of 24 irrigations during the growing season. All grains were harvested at maturity, air-dried to a moisture content of around $10 \%$, manually cleaned, vacuum packed and stored at $-20^{\circ} \mathrm{C}$ until analysis.

\subsection{Physical characteristics of grain}

The Single Kernel Characterization System (SKCS 4100, Perten Instruments, Hägersten, Sweden) was used to evaluated the physical characteristics of sorghum 
grain, and all samples were evaluated in duplicate.

\subsection{Phenolic extraction}

All sorghum whole grains were milled to pass $100 \%$ through a $500 \mu \mathrm{m}$ sieve using a grain mill (CEMOTEC 1090, Foss Tecator, Hoganäs, Sweden). For free and bound polyphenols, extraction was conducted according to the method of Svensson, Sekwati-Monang, Lutz, Schieber, \& Gänzle (2010) with some modifications. In brief, the $15 \mathrm{~mL}$ of $80 \%(\mathrm{v} / \mathrm{v})$ aqueous methanol was mixed with around $2 \mathrm{~g}$ of the ground sample under $\mathrm{N}_{2}$, and the mixture was shaken in the water bath at $25^{\circ} \mathrm{C}$ for $2 \mathrm{~h}$. The supernatant was collected after centrifuging at $3,220 \times \mathrm{g}$ for $10 \mathrm{~min}$ at $4^{\circ} \mathrm{C}$. The residue was extracted with $20 \mathrm{~mL} \mathrm{80 \%} \mathrm{(v/v)} \mathrm{aqueous} \mathrm{methanol} \mathrm{two} \mathrm{times} \mathrm{more,} \mathrm{and}$ all supernatants were combined after centrifuging. Rotary vacuum evaporation was carried out to evaporate supernatants to dryness. The resulting solid was re-dissolved in $10 \mathrm{~mL}$ of methanol and stored at $-20^{\circ} \mathrm{C}$ under $\mathrm{N}_{2}$. The residue remaining after free polyphenol extraction was the used for bound phenolic extraction.

For the extraction of bound phenolic compounds, the residue after free polyphenol extraction was mixed with $15 \mathrm{~mL}$ of $2 \mathrm{M}$ hydrochloric acid $(\mathrm{HCl})$ under $\mathrm{N}_{2}$ in the water bath at $100^{\circ} \mathrm{C}$ for $1 \mathrm{~h}$. After hydrolyzing, the $15 \mathrm{~mL}$ ethyl acetate was added and thorough mixed. Then, the ethyl acetate fraction was collected after partitioning. The hydrolysate was re-extracted with the $15 \mathrm{~mL}$ ethyl acetate four times more, and all ethyl acetate fractions were combined and evaporated to dryness. The resulting solid was re-dissolved in $10 \mathrm{~mL}$ of methanol and stored at $-20^{\circ} \mathrm{C}$ under $\mathrm{N}_{2}$ before analysing. 
2.4. HPLC-DAD-ESI-MS $S^{n}$ analysis

An Agilent 1290 UHPLC system with diode array detector (DAD) and Agilent 6460 LC-QQQ LC-MS/MS System (Agilent Technologies, Palo Alto, CA, USA) were used to separate polyphenols according to the procedure described in detail previously (Wu et al., 2016b). Briefly, the Kinetex XB-C 18 reversed phase-HPLC column ( $5 \mu \mathrm{m}$, $250 \times 4.6 \mathrm{~mm}$, Phenomenex, Torrance, CA, USA) was used to separate individual phenolic compounds, and the scanning range of the DAD was set between 190 and $600 \mathrm{~nm}$ at steps of $2 \mathrm{~nm}$. Solvent A was $0.1 \%$ formic acid in LC-MS grade water (Honeywell Burdick \& Jackson, Gillman, SA, Australia), and solvent B consisted of LC-MS grade acetonitrile (Honeywell Burdick \& Jackson, Gillman, SA, Australia). Extract $(5 \mu \mathrm{L})$ was injected and the following linear gradient elution was used: $5 \%-15 \%$ B (5 min), 15\%-50\% B (40 min), 50\%-70\% B (2 min), 70\%-100\% B (1 min), 100\% B (7 $\mathrm{min}), 100 \%-5 \% \mathrm{~B}(1 \mathrm{~min}), 5 \% \mathrm{~B}(9 \mathrm{~min})$. The rate of flow was $0.5 \mathrm{ml} / \mathrm{min}$.

Mass spectra were performed in the ESI negative mode with a scan time of $2000 \mathrm{MS}$ under the following conditions: gas $\left(\mathrm{N}_{2}\right) 5 \mathrm{~L} / \mathrm{min}$ at $300{ }^{\circ} \mathrm{C}$, nebulizer 45 psi, sheath gas $\left(\mathrm{N}_{2}\right) 11 \mathrm{~L} / \mathrm{min}$ at $250^{\circ} \mathrm{C}$, capillary voltage $-3.5 \mathrm{kV}$ and nozzle voltage $-500 \mathrm{~V}$. Phenolic compounds were detected by full scan ranging from m/z 50 to 1300 .

\subsection{Quantification of polyphenols}

The following individual authentic standards were used for quantitation. Ferulic acid, caffeic acid, luteolin, apigenin, taxifolin and naringenin were purchased form Sigma-Aldrich (St. Louis, MO, USA). Luteolinidin chloride, and apigeninidin chloride were purchased from Alsachim (Strasbourg, France). Results were expressed 
as $\mu \mathrm{g} / \mathrm{g}$ sample $(\mathrm{db})$. All extracts were analysed in duplicate.

\subsection{Statistical analysis}

All data were reported as means \pm standard deviation (SD) using SPSS Statistics V20 (IBM Corp., Armonk, NY, USA). The main effects of genotype and irrigation and their interaction were analysed using a two-way ANOVA with Tukey post-hoc test. $P \leq 0.05$ was considered significantly different. A principal components analysis was run on the complete dataset for each irrigation treatment using Statistica 10 (Dell Software., Tulsa, Oklahoma, USA). A correlation matrix across all the variables within an irrigation treatment was run to check if any of the variables were highly correlated with any of the other variables prior to running the PCA. A plot of principal components 1 and 2 ( $\mathrm{PC} 1$ and $\mathrm{PC} 2$ ) for each irrigation treatment enabled the genotypes to be clustered into a number of groups based on their expression of the polyphenolic compounds. An analysis of variance was used to test the significance of these groups.

\section{Results}

\subsection{Kernel physical characteristics}

Genotype, irrigation regime and their interaction had a significant influence on weight and diameter of sorghum grain (Fig. 1) $(P \leq 0.05)$. The values of grain weight and diameter were significantly reduced when reducing the amount of irrigation in all sorghum genotypes. Sorghum Shawaya Short Black 1 had the highest values of grain weight and diameter under the three irrigation regimes, while the lowest values were in sorghum IS8237C under FI and DI regimes and Alpha under SDI regime. 
187

188

189

190

191

192

193

194

195

196

197

198

199

200

201

202

203

204

205

206

207

208

\subsection{Identification of polyphenols}

Individual phenolic compounds in the six sorghum genotypes from three irrigation regimes were monitored by HPLC-DAD and mass spectrometry (MS) detection. Representative HPLC chromatograms of phenolic compounds in the genotype of MR Bazley are presented in Fig 1. The MS and UV characteristics of the chromatographic peaks from all samples, along with their proposed structure, are shown in Table 1 . The 25 different phenolic compounds were identified in the extracts. A total of eight individual polyphenols, including ferulic acid, caffeic acid, luteolin, apigenin, luteolinidin, apigeninidin, taxifolin and naringenin, were unequivocally identified and another 17 tentatively identified.

Peaks, 8, 9, 13, 16, 17, 21, 24 and 25 were identified by authentic standards based on their chromatographic comparisons. Peaks 2, 5-7, 11, 14-15, 18-20 and 22-23 were identified in detail in our previous study (Wu et al., 2016b). Of the other peaks, Peak $\mathbf{1}$ represents an unknown complex polyphenol. It was noted that peak $\mathbf{3}$ had similar UV and MS spectra to peaks 18 and 19, and was tentatively identified as 1,2-O-dicaffeoylglycerol or 1,3-O-dicaffeoylglycerol isomer. Peak 4 had a deprotonated molecule $[\mathrm{M}-\mathrm{H}]^{-}$ions at $m / z 353$, and prominent fragment ions at $m / z$ 191 and 173, corresponding to deprotonated quinic acid and caffeic acid fragments, respectively. After comparisons with the literature (Han et al., 2008), peak 4 was tentatively identified as chlorogenic acid (5-caffeoylquinic acid). Peak 10 had a deprotonated molecule $[\mathrm{M}-\mathrm{H}]^{-}$at $m / z$ 447. The $[\mathrm{M}-\mathrm{H}-162]^{-}$ion at $m / z 285$ is typical of that produced by the loss of a hexoside residue, and the prominent fragment ions at 
$\mathrm{m} / \mathrm{z} 285$ would correspond to the deprotonated luteolin fragment. Hence, peak $\mathbf{1 0}$ was tentatively identified as luteolin hexoside. Peak 12, with a deprotonated molecule $211[\mathrm{M}-\mathrm{H}]^{-}$at $\mathrm{m} / \mathrm{z}$ 433, also lost a hexoside residue (433- 162) to produce the prominent 212 fragment ions at $\mathrm{m} / \mathrm{z}$ 271, which could correspond to deprotonated naringenin 213 fragment. Therefore, peak 12 was tentatively identified as naringenin hexoside (Table $2141)$.

3.3. Influence of genotype and irrigation regime on the profiles of polyphenols of 216 grains

217 The representative HPLC chromatograms of free polyphenols in the MR-Bazley genotype are shown in Fig 1. The HPLC chromatograms illustrated that across all 219 genotypes, irrigation treatments did not differ in the polyphenolic species present 220 rather only altered their concentrations. The profiles of both free and bound forms of 221 individual polyphenols of six sorghum genotypes under three irrigation regimes are 222 shown in Supplementary Table S2.

3.4. Influence of genotype and irrigation on the individual polyphenol concentration of grains

225 It is important to understand the presence and concentrations of individual 226 polyphenols for specific applications of the grain, such as for high antioxidant health 227 foods (Yousif, Nhepera, \& Johnson, 2012), as the antioxidant properties of sorghum 228 grain relate to both polyphenol concentration and profile (Wu et al., 2016b; Wu et al., 229 2016c). In the present study eight phenolic compounds were quantified based on the 230 availability of authentic standards. Based on their structural characteristics, the 
quantified phenolics were classified into five groups and their concentrations determined.

Hydroxycinnamic acids. The hydroxycinnamic acids quantified were caffeic acid and ferulic acid (Table 2). The free, bound and total levels of these compounds were significantly affected by genotype, irrigation regime and their interaction ( $p \leq 0.05)$. Under the FI regime, the highest and lowest free and total caffeic acid concentrations were found in Alpha and IS1311C, respectively. For total ferulic acid concentration under the FI regime, IS8237C had the lowest while MR-Bazley had the highest. Water deficit treatments significantly increased the level of free ferulic acid as compared to the FI treatment. A reduction in the amount of irrigation water resulted in varying changes in both bound caffeic acid and ferulic acid concentration amongst the genotypes. Under the SDI regime, Liberty had the lowest concentrations of total caffeic acid and ferulic acid, while IS1311C and MR-Bazley had the highest total caffeic acid and total ferulic acid contents, respectively.

3-Deoxyanthocyanidins. The concentration of luteolinidin and apigeninidin is presented in Table 3. Again, the concentrations of these compounds were significantly influenced by genotype, irrigation regime and their interaction $(p \leq 0.05)$. Luteolinidin and apigeninidin were not detected in the white sorghum, Liberty. Otherwise the lowest detectable concentrations of free luteolinidin and apigeninidin were in MR-Bazley and Alpha under FI regime, respectively, while Shawaya Short Black 1 had the highest values of these two compounds. The intermediate DI regime resulted in a higher concentration of luteolinidin than under the FI and SDI regimes. 
The concentration of both bound luteolinidin and apigeninidin varied with decreasing water supply and genotype Shawaya Short Black 1 had the highest contents of total luteolinidin and apigeninidin under both FI and DI regimes, but became the lowest under SDI regime when compared with other genotypes.

Flavones. Two flavones were quantified in the samples namely luteolin and apigenin (Table 3), with significant changes in concentrations $(p \leq 0.05)$ due to genotype, irrigation regime and their interaction. No apigenin in free or bound form was detected in Liberty or Alpha under the three irrigation regimes. Free and total luteolin and apigenin concentrations were the highest $(p \leq 0.05)$ under the DI regime across all genotypes. Shawaya Short Black 1 contained the highest contents of free and total luteolin, but the lowest contents of free, bound and total apigenin under FI regime. However, differing irrigation regimes resulted in different levels of bound luteolin and apigenin concentrations. Compared to FI and SDI regimes, the higher contents of free, bound and total luteolin and apigenin were in all sorghum genotypes under DI regime. Irrespective of treatment, the lowest contents of free, bound and total apigenin were in Shawaya Short Black 1.

Dihydroflavonol and Flavanones. One dihydroflavonol taxifolin and one flavanone naringenin were identified and quantified, and their concentrations were significantly affected by genotype, irrigation regime and their interaction $(p \leq 0.05)$, as shown in Table 3. Free, bound and total taxifolin and naringenin concentrations were highest under the intermediate DI regime when compared to the FI and SDI regimes across all genotypes, with the exception of Liberty, where taxifolin and naringenin were not 
detected. The lowest detected concentration of total taxifolin was in Alpha, while both IS1311C and IS8237C had the lowest detected concentration of total naringenin under the DI regime.

\subsection{Principal component analysis $(P C A)$}

A PCA of the six sorghum genotypes using the quantitative polyphenolic variables found that $86.36 \%, 83.90 \%$ and $90.18 \%$ of the variation could be explained by the first three components under FI, DI and SDI treatments, respectively, (Tables S4-S6). A plot of PC1 and PC2 is shown in Figure 3, where it can be seen that a number of individual polyphenols form distinct groups under three irrigation treatments. Three, four and four groups were identified under FI, DI and SDI treatments, respectively. Under FI treatment (Fig 3a), Group B (Shawaya Short Black 1) has a high level of individual flavonoids, while Group A (Alpha and MR-Bazley) has high individual hydroxycinnamic acids. For DI regime, a high level of individual flavonoids is presented in Group B (Shawaya Short Black 1), but Group A (Alpha, MR-Bazley and IS8237C) has low levels of individual polyphenols. Group C (Liberty) has a low level of individual polyphenols, while a high level of some individual flavonoids is found in Group B (Shawaya Short Black 1) or Group D (IS1311C). To evaluate the significance of the groupings, an analysis of variance was run on both PC1 and PC2 with the groups listed above used as the treatment. Both PC1 and PC2 were shown to have a significant difference between the groups ( $p \leq 0.05)$, across all of the irrigation treatments.

\section{Discussion}


characteristics. The range of grain weight and diameter in the present study was in the

range of previous reports (Liu et al., 2013; Wu et al., 2008; Wu et al 2016c). However,

both Liu et al. (2013) and Wu et al. (2008) reported that the values of grain weight

and diameter were not significantly influenced by reduced irrigation levels. The

differences recorded in this study may be caused by the severe water stress on the SDI

treatment and the higher daytime temperatures present during the growing season

(Supplementary Fig S1).

Deficit irrigation had a significant influence on individual polyphenols. Some key

enzymes involved in the biosynthesis of individual polyphenols, have been previously identified including phenylalanine ammonia lyase (PAL), chalcone synthase (CHS) and flavonoid-3'-hydroxylase (F3'H) (Cohen \& Kennedy, 2010). Synthesis of enzymes, and the synthesis of these two enzymes was reported to be enhanced under biotic stress in sorghum, which led to increased 3-deoxyanthocyanidin concentration concentration was the highest under DI regime across all genotypes when compared

314 with other regimes. Therefore, it is proposed that more CHS and F3' $\mathrm{H}$ enzymes might 315 be synthesized when irrigation level was reduced from FI to DI. However, more research work will be needed to confirm this hypothesis. Additionally, the effect of 317 water deficit on the metabolic pathways of other individual polyphenols is still 318 unknown in sorghum, so further research is required to understand these pathways. 
In the present study, some individual polyphenols significantly decreased in concentration when irrigation was decreased from DI to SDI regime. These findings contrast with other reports, in which polyphenol concentration increased when the level of irrigation decreased (Artajo, Romero, Tovar, \& Motilva, 2006; Buendía et al., 2008; Martinelli, Basile, Morelli, d'Andria, \& Tonutti, 2012; Tovar et al., 2001). Normal physiological and biochemical plant processes can be inhibited by severe water deficit through reduced cell elongation and reduced photosynthesis (Jahanzad et al., 2013; Saeed \& El-Nadi, 1998). In the present study, sorghum grain yield was the lowest under SDI treatment (data not shown), with no sorghum grain set in sorghum IS8237C, which indicated that the SDI regime may have seriously inhibited physiological and biochemical processes compared with FI and DI regimes. It is proposed therefore that the synthesis of polyphenols might be also have been inhibited under the SDI regime. Temperatures above $35^{\circ} \mathrm{C}$ have also been reported to decrease the concentration of total and individual polyphenols in sorghum grain (Wu et al., 2016b; Wu et al., 2016c). The average maximum daytime temperature during the growth of the sorghum plants in the present study was in fact in excess of $35^{\circ} \mathrm{C}$, 335 (Supplementary Fig S1). As the sorghum was unable to regulate the severe water 336 stress, the high temperature might also have decreased the biosynthesis of 337 polyphenols, flavonoids and some individual polyphenols on the sorghum grain under the SDI regime. These findings might provide valuable information about polyphenol concentrations in plants grown under a Mediterranean climate, such as the 
which plant biochemical and physiological processes are mainly regulated by water deficit coupled with other interacting factors, such as high temperatures.

The profiles of individual polyphenols in the sorghum grain varied among the different genotypes. Two different red sorghums: MR-Bazley and Alpha were planted in this study, but only Alpha lacked apigenin (Supplementary Table S1). Taleon et al. (2014) also supported that not all red sorghum genotypes contained luteolin.

The concentration of individual polyphenols determined in this study is in agreement with previous studies (Dykes et al., 2009; Taleon et al., 2012; Wu et al., 2016b). Black sorghum had the highest levels of 3-deoxyanthocyanidins when compared to other genotypes, suggesting that black sorghum is a predominant source of this group of compounds. Similar results have been reported by Taleon et al. (2012). The accumulation of 3-deoxyanthocyanidins in sorghum grain is regulated by $P 1$, which is controlled by Yellow seedl gene (Ibraheem, Gaffoor, \& Chopra, 2010). As no 3-deoxyanthocyanidins were detected in white sorghum Liberty, it is proposed that Yellow seedl gene might be absent in this genotype. The luteolin concentration of the two red genotypes, MR-Bazley and Alpha was significantly different from each other (Table 3). Previously published data on two other red sorghum genotypes, Tx2911 and 98CA4779 reported that they contained 10.8 and $13.4 \mu \mathrm{g} / \mathrm{g}$ luteolin, respectively (Dykes et al., 2009), more than about twice higher than our values, which indicates that the individual flavonoid concentration cannot be simply predicted by grain color. These results highlight that before producing sorghum products with target levels of specific polyphenols, such as 3-deoxyanthocyanidins for potential health benefits, it is 
essential to evaluate the profile and concentration of the individual polyphenols in the genotype being used.

365 PCA is one of the oldest and most widely used techniques for reducing the dimensionality and increasing the interpretability of large datasets (Jolliffe \& Cadima, 2016). The success of PCA can be seen in Rodríguez-Delgado, González-Hernández, Conde-González, \& Pérez-Trujillo (2012), who used PCA to understand the polyphenol content of 55 samples of red wines from different locations, with all samples separated into three groups according to geographical area of origin. In the present study, classification of sorghum genotypes into several groups was possible when a two-dimensional plot of the first two principal components was used to 373 evaluate the scores of each sorghum sample. It is also noticed that three of six genotypes always fall in to the same groups: Group A and Group B. However, the 375 levels of polyphenols vary depending on the irrigation treatment (Fig. 3), suggesting that irrigation treatment modifies polyphenol content of these genotypes. Dietary 377 intake of whole sorghum grain with abundant levels of polyphenols has potential to 378 reduce the risk of certain cancers, cardiovascular disease and type 2 diabetes, owning 379 to their antioxidant properties (Stefoska-Needham et al., 2015). The free, bound and total antioxidant capacity in sorghum grains as affected by irrigation treatments was 381 evaluated by 3-ethylbenzothiazoline-6-sulfonic acid diammonium salt (ABTS) and 382 the 2-2-diphenyl-1-picrylhydrazyl (DPPH) assays, and all data was presented in the 383 Supporting Information Table S3. In the present study, sorghum Shawaya Short Black 3841 had the highest concentration of total polyphenols and flavonoids, followed by 
IS8237C, a brown-coloured grain and these two genotypes also had higher

concentration of antioxidant activity (Supplementary Table S2 and S3). Recently, several sorghum products, such as pasta (Khan, Yousif, Johnson, \& Gamlath, 2013) and extruded snack food (Licata et al., 2015), have been developed to enhance antioxidant capacity of these food products. Khan, Yousif, Johnson, and Gamlath (2015) reported that in comparison with $100 \%$ durum wheat pasta and pasta 391 containing $30 \%$ white wholegrain sorghum, the antioxidant status through increasing 392 plasma polyphenols, antioxidant capacity and superoxide dismutase activity was 393 increased post-prandially in healthy human participants after consuming pasta 394 containing $30 \%$ red wholegrain sorghum flour. It was suggested that these differences 395 may be due to the higher polyphenol content and the different profile of polyphenolic compounds found in red wholegrain sorghum flour compared to white wholegrain 397 sorghum flour and durum wheat, probably due to the presence of

398 3-deoxyanthocyanidins in red wholegrain sorghum flour only (Khan et al., 2013).

\section{5. Conclusion}

400 In conclusion, irrigation, genotype and their interaction had a significant influence 401 on individual polyphenols, and most of them showed the highest concentration under 402 the intermediate DI regime. The present study suggested that both irrigation regime 403 and genotype should be considered when selecting sorghum genotypes to plant for the 404 production of high antioxidant value health foods and/or nutraceuticals. 


\section{Acknowledgments}

406 This work was supported by Curtin International Postgraduate Research Scholarships

407 (CIPRS), Curtin University, Australia. The author GW would like to thank Mr John 408 Jackson in Department of Environment and Agriculture, School of Science, Curtin 409 University for helping us to plant sorghums. Analysis for this work was performed by 410 the CMCA (Metabolomics Australia) and was supported by infrastructure funding

411 from the Western Australian State Government in partnership with the Australian 412 Federal Government, through the National Collaborative Research Infrastructure 413 Strategy (NCRIS). 


\section{References}

Allen, R. G., Pereira, L. S., Raes, D., \& Smith, M. (1998). Crop evapotranspiration-Guidelines for computing crop water requirements-FAO Irrigation and drainage paper 56. FAO, Rome, 300 , D05109.

Artajo, L. S., Romero, M. P., Tovar, M. J., \& Motilva, M. J. (2006). Effect of irrigation applied to olive trees (Olea europaea L.) on phenolic compound transfer during olive oil extraction. European Journal of Lipid Science and Technology, 108 , 19-27.

Awika, J. M., \& Rooney, L. W. (2004). Sorghum phytochemicals and their potential impact on human health. Phytochemistry, 65 , 1199-1221.

Boddu, J., Svabek, C., Sekhon, R., Gevens, A., Nicholson, R. L., Jones, A. D., Pedersen, J. F., Gustine, D. L., \& Chopra, S. (2004). Expression of a putative flavonoid 3'-hydroxylase in sorghum mesocotyls synthesizing 3-deoxyanthocyanidin phytoalexins. Physiological and Molecular Plant Pathology, 65 , 101-113.

BOM. (2013). Bureau of Meteorology. http://www.bom.gov.au/. Accessed 13.07.2014.

Buendía, B., Allende, A., Nicolás, E., Alarcón, J. J., \& Gil, M. I. (2008). Effect of regulated deficit irrigation and crop load on the antioxidant compounds of peaches. Journal of Agricultural and Food Chemistry, 56 , 3601-3608.

Cohen, S. D., \& Kennedy, J. A. (2010). Plant metabolism and the environment: Implications for managing phenolics. Critical Reviews in Food Science and 
437 Dykes, L., \& Rooney, L. (2007). Phenolic compounds in cereal grains and their health benefits. Cereal Foods World, 52, 105-111.

439

440

441

442

443

444

445

446

447

448

449

450

451

452

453

454

455

456

457

Dykes, L., Seitz, L. M., Rooney, W. L., \& Rooney, L. W. (2009). Flavonoid composition of red sorghum genotypes. Food Chemistry, 116, 313-317.

Han, J., Ye, M., Qiao, X., Xu, M., Wang, B.-r., \& Guo, D.-A. (2008). Characterization of phenolic compounds in the Chinese herbal drug Artemisia annua by liquid chromatography coupled to electrospray ionization mass spectrometry. Journal of Pharmaceutical and Biomedical Analysis, 47, 516-525.

Ibraheem, F., Gaffoor, I., \& Chopra, S. (2010). Flavonoid phytoalexin-dependent resistance to anthracnose leaf blight requires a functional yellow seed1 in Sorghum bicolor. Genetics, 184, 915-926.

Jahanzad, E., Jorat, M., Moghadam, H., Sadeghpour, A., Chaichi, M.-R., \& Dashtaki, M. (2013). Response of a new and a commonly grown forage sorghum cultivar to limited irrigation and planting density. Agricultural Water Management, 117, 62-69.

Jolliffe, I. T., \& Cadima, J. (2016). Principal component analysis: a review and recent developments. Philosophical Transactions of the Royal Society A Mathematical Physical \& Engineering Sciences, 374, 20150202.

Khan, I., Yousif, A., Johnson, S. K., \& Gamlath, S. (2013). Effect of sorghum flour addition on resistant starch content, phenolic profile and antioxidant capacity of durum wheat pasta. Food Research International, 54, 578-586. 
Khan, I., Yousif, A. M., Johnson, S. K., \& Gamlath, S. (2015). Acute effect of sorghum flour-containing pasta on plasma total polyphenols, antioxidant capacity and oxidative stress markers in healthy subjects: A randomised controlled trial. Clinical Nutrition, 34, 415-421.

Licata, R., Coorey, R., Zhao, Y., Chu, J., \& Johnson, S. (2015). Maximizing slowly digested starch in an expanded sorghum- maize extruded food using response surface methodology. Starch- Stärke, 67 , 285-293.

Liu, L., Maier, A., Klocke, N. L., Yan, S., Rogers, D. H., Tesso, T., \& Wang, D. (2013). Impact of deficit irrigation on sorghum physical and chemical properties and ethanol yield. Transactions of the ASABE, 56, 1541-1549.

Lo, S.-C. C., De Verdier, K., \& Nicholson, R. L. (1999). Accumulation of 3-deoxyanthocyanidin phytoalexins and resistance to Colletotrichum sublineolum in sorghum. Physiological and Molecular Plant Pathology, 55, 263-273.

Martinelli, F., Basile, B., Morelli, G., d'Andria, R., \& Tonutti, P. (2012). Effects of irrigation on fruit ripening behavior and metabolic changes in olive. Scientia Horticulturae, 144, 201-207.

Pachauri, R. K., Allen, M., Barros, V., Broome, J., Cramer, W., Christ, R., Church, J., Clarke, L., Dahe, Q., \& Dasgupta, P. (2014). Climate Change 2014: Synthesis Report. Contribution of Working Groups I, II and III to the Fifth Assessment Report of the Intergovernmental Panel on Climate Change.

Rodríguez-Delgado, M. Á., González-Hernández, G., Conde-González, J. E., \& 
Pérez-Trujillo, J. P. (2002). Principal component analysis of the polyphenol content in young red wines. Food Chemistry, 78, 523-532.

Saeed, I., \& El-Nadi, A. (1998). Forage sorghum yield and water use efficiency under variable irrigation. Irrigation Science, 18, 67-71.

484

485

Stefoska-Needham, A., Beck, E. J., Johnson, S. K., \& Tapsell, L. C. (2015). Sorghum: an underutilized cereal whole grain with the potential to assist in the prevention of chronic disease. Food Reviews International, 31, 401-437.

Svensson, L., Sekwati-Monang, B., Lutz, D. L., Schieber, A., \& Gänzle, M. G. (2010). Phenolic acids and flavonoids in nonfermented and fermented red sorghum (Sorghum bicolor (L.) Moench). Journal of Agricultural and Food Chemistry, 58, 9214-9220.

Taleon, V., Dykes, L., Rooney, W., \& Rooney, L. (2012). Effect of genotype and environment on flavonoid concentration and profile of black sorghum grains. Journal of Cereal Science, 56, 470-475.

Taleon, V., Dykes, L., Rooney, W., \& Rooney, L. (2014). Environmental effect on flavonoid concentrations and profiles of red and lemon-yellow sorghum grains. Journal of Food Composition and Analysis, 34, 178-185.

Taylor, J. R., Schober, T. J., \& Bean, S. R. (2006). Novel food and non-food uses for sorghum and millets. Journal of Cereal Science, 44 , 252-271.

Tovar, M. J., Motilva, M. J., \& Romero, M. P. (2001). Changes in the phenolic composition of virgin olive oil from young trees (Olea europaea L. cv. Arbequina) grown under linear irrigation strategies. Journal of Agricultural 
and Food Chemistry, 49, 5502-5508.

503

504

505

506

507

508

509

510

511

512

513

514

515

516

517

518

519

520

521

522

523

Wu, G., Johnson, S. K., Bornman, J. F., Bennett, S. J., Singh, V., Simic, A., \& Fang, Z. (2016a). Effects of genotype and growth temperature on the contents of tannin, phytate and in vitro iron availability of sorghum grains. PloS One, 11, e0148712.

Wu, G., Johnson, S. K., Bornman, J. F., Bennett, S. J., Clarke, M. W., Singh, V., \& Fang, Z. (2016b). Growth temperature and genotype both play important roles in sorghum grain phenolic composition. Scientific Reports, 6, 21835.

Wu, G., Johnson, S., Bornman, J., Bennett, S., Singh, V., \& Fang, Z. (2016c). Effect of genotype and growth temperature on sorghum grain physical characteristics, polyphenol content and antioxidant activity. Cereal Chemistry, 93, 419-425.

Wu, G., Johnson, S. K., Bornman, J. F., Bennett, S. J., \& Fang, Z. (2017). Changes in whole grain polyphenols and antioxidant activity of six sorghum genotypes under different irrigation treatments. Food Chemistry, 214, 199-207.

Wu, X., Zhao, R., Liu, L., Bean, S., Seib, P. A., McLaren, J., ... \& Wang, D. (2008). Effects of growing lcation and irrigation on attributes and ethanol yields of selected grain sorghums. Cereal Chemistry, 85, 495-501.

Yousif, A., Nhepera, D., \& Johnson, S. (2012). Influence of sorghum flour addition on flat bread in vitro starch digestibility, antioxidant capacity and consumer acceptability. Food Chemistry, 134, 880-887.

Zarrouk, O., Francisco, R., Pinto-Marijuan, M., Brossa, R., Santos, R. R., Pinheiro, C., Costa, J. M., Lopes, C., \& Chaves, M. M. (2012). Impact of irrigation regime 
Figure.1. Weight (a) and diameter (b) of sorghum grain as affected by irrigation

529 treatments.

${ }^{\text {a-e }}$ Values with different superscripts in the same irrigation treatment are significantly different $(P \leq 0.05)$. A, B Values with different superscripts in the same genotype with different irrigation treatments are significantly different $(P \leq 0.05)$.

Abbreviations: $\mathrm{FI}=$ full irrigation; $\mathrm{DI}=$ deficit irrigation; $\mathrm{SDI}=$ severe deficit irrigation

Figure.2. Representative chromatograms of sorghum grain free polyphenols from genotype MR-Bazley A: under full irrigation regime; B: under deficit irrigation regime; $\mathrm{C}$ : under severe deficit irrigation regime.

Figure.3. Variable projections after principal component analysis (PCA) on six sorghum genotypes a: under full irrigation regime; b: under deficit irrigation regime; c: under severe deficit irrigation regime.

Abbreviations: Polyphenols (FCA = free caffeic acid; $\mathrm{BCA}=$ bound caffeic acid; $\mathrm{TCA}=$ total caffeic acid; FFA = free ferulic acid; BFA = bound ferulic acid; TFA = total ferulic acid; FLUT $=$ free lutedinidin; BLUT $=$ bound lutedinidin $;$ TLUT $=$ total lutedinidin; FAPI $=$ free apigenidin; BAPI = bound apigenidin; TAPI = total apigenidin; FTA $=$ free taxifolin; $\mathrm{BTA}=$ bound taxifolin; TTA = total taxifolin; FLU = free luteolin; BLU = bound luteolin; TLU = total luteolin; FNAR = free narigenin; $\mathrm{BNAR}=$ bound narigenin; $\mathrm{TNAR}=$ total narigenin; $\mathrm{FAP}=$ free apigenin; BAP = bound apigenin; TAP = total apigenin $) ;$ Genotypes $(\mathrm{G} 1$ = Liberty; 
G2 = MR-Bazley; G3 = Alpha; G4 = IS1311C; G5 = IS8237C; G6 = Shawaya Short Black 1) 
Table 1. Identification of individual polyphenols in sorghum grains by HPLC-DAD-ESIMS fragmentation and in comparison with respective standards.

\begin{tabular}{|c|c|c|c|c|c|}
\hline $\begin{array}{l}\text { Peak } \\
\text { No. }\end{array}$ & $\begin{array}{l}\mathrm{Rt}^{\mathrm{a}} \\
(\mathrm{min})\end{array}$ & $\lambda_{\max }(\mathrm{nm})$ & $m / z[\mathrm{M}-\mathrm{H}]^{-}$ & $m / z \mathrm{MS}^{2}$ (Abundance $\%$ ) & Tentative identification \\
\hline 1 & 10.1 & 275 & 479 & $149(4), 121(8), 105(4)$ & Unknown \\
\hline 2 & 10.9 & 280 & 577 & 425 (60), 289 (26) & Procyanidin B1 \\
\hline 3 & 11.8 & $325,300 \mathrm{sh}^{\mathrm{b}}$ & 415 & 253 (100), $161(11), 135(85)$ & 1,2-O-dicaffeoylglycerol isomer \\
\hline 4 & 12.3 & 330 & 353 & $191(100), 173$ (48), 85 (7) & Chlorogenic acid \\
\hline 5 & 13.1 & $326,298 \mathrm{sh}$ & 253 & $179(1), 161(100), 135(65)$ & 2-O-caffeoylglycerol \\
\hline 6 & 13.5 & 280.310 & 137 & $109(35)$ & Protocatechuic aldehyde \\
\hline 7 & 14.4 & $326,298 \mathrm{sh}$ & 253 & $179(1), 161(100), 135(65)$ & 1-O-caffeoylglycerol \\
\hline 8 & 15.0 & 297,322 & 179 & $135(100)$ & Caffeic acid $\left(\operatorname{std}^{c}\right)$ \\
\hline 9 & 16.1 & 280,490 & 269 & $241(11), 225(27), 169$ (19), $133(30)$ & Luteolinidin (std) \\
\hline 10 & 17.0 & 290 & 447 & $285(45)$ & Luteolin hexoside \\
\hline 11 & 17.7 & 310 & 237 & $163(20), 145(50), 119(31)$ & 2-O-p-coumaroylglycerol \\
\hline 12 & 18.0 & 285 & 433 & $271(86) ; 151(56)$ & Naringenin hexoside \\
\hline 13 & 18.3 & 275,470 & 253 & $225(10), 209(70), 179(40), 117$ (65) & Apigeninidin (std) \\
\hline 14 & 19.1 & 283 & 433 & 287 (100), $151(59)$ & Eriodictyol deoxyhexoside \\
\hline 15 & 19.2 & 310 & 163 & $119(100)$ & $p$-coumaric acid \\
\hline 16 & 20.8 & 295,325 & 193 & $178(42), 134(100)$ & Ferulic acid (std) \\
\hline 17 & 21.6 & 288 & 303 & $285(100), 217(9), 177$ (18), $125(35)$ & Taxifolin (std) \\
\hline 18 & 28.5 & $326,300 \mathrm{sh}$ & 415 & $253(100), 179(100), 161(11), 135(85)$ & 1,2-O-dicaffeoylglycerol \\
\hline 19 & 29.4 & $326,300 \mathrm{sh}$ & 415 & $253(100), 179(100), 161(11), 135(85)$ & 1,3-O-dicaffeoylglycerol \\
\hline
\end{tabular}




\begin{tabular}{|c|c|c|c|c|c|}
\hline 20 & 30.6 & 287 & 287 & $\begin{array}{l}135(85) \\
151(10)\end{array}$ & Eriodictyol \\
\hline 21 & 31.1 & 252,347 & 285 & $\begin{array}{l}241(1), 217(3), 199(3), 175(3), 151(17), 133 \text { (13), } \\
107 \text { (3) }\end{array}$ & Luteolin (std) \\
\hline 22 & 33.3 & 219,315 & 399 & $\begin{array}{l}253(80), 235(11), 179(25), 163(86), 145(35), 119 \\
(100), 135(27)\end{array}$ & Coumaroyl-caffeoylglycerol \\
\hline 23 & 34.2 & $325,295 \mathrm{sh}$ & 429 & $\begin{array}{l}253 \text { (70), } 235 \text { (11), } 193 \text { (100), } 175 \text { (32), } 161 \text { (53), } 135 \\
(81)\end{array}$ & Feruloyl-caffeoylglycerol \\
\hline 24 & 35.9 & 266,322 & 269 & $225(21), 201(10), 183(10), 149(32), 117(100)$ & Apigenin (std) \\
\hline 25 & 36.3 & 295 & 271 & $177(10), 151(50), 119(20), 107(10)$ & Naringenin (std) \\
\hline
\end{tabular}

${ }^{\mathrm{a}} \mathrm{Rt}=$ Retention time $^{\mathrm{b}} \mathrm{sh}=\operatorname{shoulder}^{\mathrm{c}}$ std $=$ standard 
Table 2. Free, bound and total contents of hydroxycinnamic acids ( $\mu \mathrm{g} / \mathrm{g}$ dry basis) of six genotypes of sorghum grain grown under three irrigation treatments.

\begin{tabular}{|c|c|c|c|c|c|c|c|}
\hline & & \multicolumn{6}{|c|}{ Genotype } \\
\hline & & Liberty & MR-Bazley & Alpha & IS1311C & IS8237C & $\begin{array}{l}\text { Shawaya Short } \\
\text { Black } 1\end{array}$ \\
\hline \multicolumn{8}{|c|}{ Caffeic acid } \\
\hline \multirow{3}{*}{ Free } & FI & $7.18 \pm 0.29$ eВ & $5.04 \pm 0.10^{\mathrm{bA}}$ & $12.55 \pm 0.29^{\mathrm{fA}}$ & $4.51 \pm 0.38^{\mathrm{aA}}$ & $5.54 \pm 0.26^{\mathrm{cA}}$ & $6.49 \pm 0.53 \mathrm{dC}$ \\
\hline & DI & $10.64 \pm 0.82^{\mathrm{cC}}$ & $9.84 \pm 0.21 \mathrm{bC}$ & $19.76 \pm 0.67^{\mathrm{eC}}$ & $9.34 \pm 0.62^{\mathrm{bB}}$ & $14.9 \overline{7} \pm 0.25 \mathrm{~dB}$ & $5.08 \pm 0.17 \mathrm{aA}$ \\
\hline & SDI & $6.44 \pm 0.18^{\mathrm{bA}}$ & $6.78 \pm 0.32$ bВ & $13.00 \pm 0.18 \mathrm{~dB}$ & $11.38 \pm 0.48^{\mathrm{cC}}$ & No data & $5.44 \pm 0.08^{\mathrm{aB}}$ \\
\hline \multirow{3}{*}{ Bound } & FI & $5.76 \pm 0.38^{\mathrm{cA}}$ & $9.54 \pm 0.11^{\mathrm{dB}}$ & $10.47 \pm 0.34^{\mathrm{eC}}$ & $4.63 \pm 0.10^{\mathrm{bA}}$ & $4.18 \pm 0.09^{\mathrm{aB}}$ & $5.03 \pm 0.21^{\mathrm{cA}}$ \\
\hline & DI & $9.97 \pm 0.53 \mathrm{dC}$ & $7.20 \pm 0.23^{\mathrm{cA}}$ & $7.56 \pm 0.10^{\mathrm{cB}}$ & $10.38 \pm 1.17 \mathrm{~dB}$ & $3.66 \pm 0.12$ aA & $5.13 \pm 0.10^{\mathrm{bA}}$ \\
\hline & SDI & $6.98 \pm 1.03 \mathrm{aB}$ & $14.71 \pm 0.88^{\mathrm{cC}}$ & $6.97 \pm 0.28^{\mathrm{aA}}$ & $15.59 \pm 0.88^{\mathrm{cC}}$ & No data & $10.05 \pm 0.49^{\mathrm{bB}}$ \\
\hline \multirow{3}{*}{ Total } & $\mathrm{FI}$ & $12.94 \pm 0.68^{\mathrm{dA}}$ & $14.58 \pm 0.01^{\mathrm{eA}}$ & $23.21 \pm 0.77^{\mathrm{fB}}$ & $9.14 \pm 0.28^{\mathrm{aA}}$ & $9.72 \pm 0.16^{\mathrm{bA}}$ & $11.55 \pm 0.76^{\mathrm{cA}}$ \\
\hline & DI & $20.61 \pm 1.40^{\mathrm{dB}}$ & $17.04 \pm 0.43^{\mathrm{bB}}$ & $27.49 \pm 0.70^{\mathrm{eC}}$ & $19.73 \pm 1.79 \mathrm{~dB}$ & $18.62 \pm 0.16^{\mathrm{cB}}$ & $10.13 \pm 0.34^{\mathrm{aA}}$ \\
\hline & SDI & $13.42 \pm 1.21^{\mathrm{aA}}$ & $21.48 \pm 0.57^{\mathrm{dC}}$ & $19.98 \pm 0.05^{\mathrm{cA}}$ & $26.97 \pm 1.90^{\mathrm{eC}}$ & No data & $16.11 \pm 0.70^{\mathrm{bB}}$ \\
\hline \multicolumn{8}{|c|}{ Ferulic acid } \\
\hline \multirow{2}{*}{ Free } & FI & $1.18 \pm 0.20^{\mathrm{aA}}$ & $1.98 \pm 0.13 \mathrm{dA}$ & $1.58 \pm 0.21^{\mathrm{bA}}$ & $2.03 \pm 0.01 \mathrm{dA}$ & $1.55 \pm 0.12^{\mathrm{bA}}$ & $1.65 \pm 0.10^{\mathrm{aA}}$ \\
\hline & DI & $1.97 \pm 0.11^{\mathrm{aC}}$ & $2.87 \pm 0.01^{\mathrm{cC}}$ & $2.78 \pm 0.16^{\mathrm{cC}}$ & $4.83 \pm 0.20^{\mathrm{dC}}$ & $2.34 \pm 0.24$ bB & $2.36 \pm 0.07^{\mathrm{bB}}$ \\
\hline \multirow{3}{*}{ Bound } & FI & $45.87 \pm 2.14^{\mathrm{cB}}$ & $82.60 \pm 3.57^{\mathrm{ев}}$ & $60.47 \pm 1.70^{\mathrm{dB}}$ & $38.11 \pm 5.68^{\mathrm{bA}}$ & $28.87 \pm 0.75^{\mathrm{aA}}$ & $46.91 \pm 2.29^{\mathrm{cA}}$ \\
\hline & DI & $50.97 \pm 1.78$ bC & $78.75 \pm 2.10^{\mathrm{dA}}$ & $40.56 \pm 0.77 \mathrm{aA}$ & $114.82 \pm 3.59^{\mathrm{eC}}$ & $52.69 \pm 2.23 \mathrm{bcB}$ & $55.18 \pm 0.69$ св \\
\hline & SDI & $35.51 \pm 3.15^{\mathrm{aA}}$ & $100.23 \pm 1.20^{\mathrm{eC}}$ & $42.66 \pm 0.59^{\mathrm{bA}}$ & $61.01 \pm 1.67^{\mathrm{cB}}$ & No data & $66.85 \pm 2.49 \mathrm{dC}$ \\
\hline \multirow{3}{*}{ Total } & FI & $47.05 \pm 2.33^{\mathrm{cB}}$ & $84.58 \pm 3.43^{\mathrm{eB}}$ & $62.48 \pm 1.82 \mathrm{dC}$ & $40.14 \pm 5.69^{\mathrm{bA}}$ & $30.43 \pm 0.83^{\mathrm{aA}}$ & $47.87 \pm 2.94^{\mathrm{cA}}$ \\
\hline & DI & $52.94 \pm 1.89^{\mathrm{bC}}$ & $81.62 \pm 2.11^{\mathrm{dA}}$ & $43.17 \pm 0.75^{\mathrm{aA}}$ & $119.65 \pm 3.79^{\mathrm{eC}}$ & $55.03 \pm 2.47^{\mathrm{bcB}}$ & $57.72 \pm 0.76^{\mathrm{cB}}$ \\
\hline & SDI & $37.33 \pm 3.22^{\mathrm{aA}}$ & $102.54 \pm 1.37^{\mathrm{eC}}$ & $45.26 \pm 0.58^{\mathrm{bB}}$ & $63.49 \pm 1.45^{\mathrm{cB}}$ & No data & $70.61 \pm 3.32^{\mathrm{dC}}$ \\
\hline
\end{tabular}

a-f Values with different superscripts in the same row are significantly different $(P \leq 0.05)$. ${ }^{\mathrm{A}, \mathrm{B}, \mathrm{C}}$ Values with different superscripts in the same column in the same dependent variable are significantly different $(P \leq 0.05)$. 
Table 3. Free, bound and total individual flavonoid content ( $\mu \mathrm{g} / \mathrm{g}$, dry basis) of six genotypes of sorghum grain grown in three irrigation treatments.

\begin{tabular}{|c|c|c|c|c|c|c|c|c|}
\hline \multirow{2}{*}{\multicolumn{2}{|c|}{ Flavonoids }} & & \multicolumn{6}{|c|}{ Genotypes } \\
\hline & & & Liberty & MR-Bazley & Alpha & IS1311C & IS $8237 \mathrm{C}$ & $\begin{array}{l}\text { Shawaya Short } \\
\text { Black } 1\end{array}$ \\
\hline \multicolumn{9}{|c|}{ 3-Deoxyanthocyanidins } \\
\hline \multirow{8}{*}{$\begin{array}{l}\text { E. } \\
\stackrel{0}{0} \\
\text { : }\end{array}$} & \multirow[b]{2}{*}{ Free } & FI & nd & $0.26 \pm 0.04^{a B}$ & $0.48 \pm 0.09^{\mathrm{bA}}$ & $1.58 \pm 0.08^{\mathrm{cA}}$ & $4.81 \pm 0.18^{\mathrm{dA}}$ & $13.44 \pm 0.76^{\mathrm{eB}}$ \\
\hline & & $\begin{array}{l}\text { DI } \\
\text { SDI }\end{array}$ & $\begin{array}{l}\text { nd } \\
\text { nd }\end{array}$ & $\begin{array}{l}1.29 \pm 0.11^{\mathrm{aC}} \\
0.04 \pm 0.01 \mathrm{aA}\end{array}$ & $\begin{array}{l}2.30 \pm 0.04^{\mathrm{bC}} \\
1.61 \pm 0.20^{\mathrm{dB}}\end{array}$ & $\begin{array}{l}2.42 \pm 0.44^{\mathrm{cB}} \\
1.49 \pm 0.20^{\mathrm{cA}}\end{array}$ & $\begin{array}{l}6.90 \pm 0.13^{\mathrm{dB}} \\
\text { No data }\end{array}$ & $\begin{array}{l}18.25 \pm 0.98^{\mathrm{eC}} \\
1.34 \pm 0.10^{\mathrm{bA}}\end{array}$ \\
\hline & \multirow{3}{*}{ Bound } & FI & nd & $3.31 \pm 0.16^{\mathrm{dB}}$ & $0.71 \pm 0.05^{\mathrm{aA}}$ & $0.84 \pm 0.06^{\mathrm{bC}}$ & $2.15 \pm 0.04^{\mathrm{cA}}$ & $11.72 \pm 0.73^{\mathrm{eB}}$ \\
\hline & & DI & nd & $8.91 \pm 0.57 \mathrm{dC}$ & $3.11 \pm 0.24^{\mathrm{bB}}$ & $0.66 \pm 0.15^{\mathrm{aB}}$ & $4.41 \pm 0.10^{\mathrm{cB}}$ & $11.60 \pm 1.40^{\mathrm{eB}}$ \\
\hline & & SDI & nd & $2.86 \pm 0.13^{\mathrm{cA}}$ & $0.68 \pm 0.10^{\mathrm{bA}}$ & $0.30 \pm 0.02^{\mathrm{aA}}$ & No data & $0.34 \pm 0.07^{\mathrm{aA}}$ \\
\hline & \multirow{3}{*}{ Total } & FI & nd & $3.56 \pm 0.20^{\mathrm{cA}}$ & $1.20 \pm 0.05^{\mathrm{aA}}$ & $2.41 \pm 0.01^{\text {bB }}$ & $5.95 \pm 0.21^{\mathrm{dA}}$ & $25.16 \pm 0.04^{\mathrm{eB}}$ \\
\hline & & DI & nd & $10.21 \pm 0.23^{\text {bB }}$ & $5.41 \pm 0.20^{\mathrm{cC}}$ & $3.08 \pm 0.59^{\mathrm{aC}}$ & $7.36 \pm 0.21^{\mathrm{dB}}$ & $29.98 \pm 0.51^{\mathrm{eC}}$ \\
\hline & & SDI & nd & $2.90 \pm 0.55^{\mathrm{cC}}$ & $2.33 \pm 0.12^{\mathrm{bB}}$ & $1.79 \pm 0.22 \mathrm{aA}$ & No data & $1.73 \pm 0.21^{\mathrm{aA}}$ \\
\hline \multirow{8}{*}{ 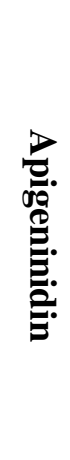 } & \multirow{3}{*}{ Free } & FI & nd & $1.02 \pm 0.11^{\mathrm{bB}}$ & $0.68 \pm 0.07^{\mathrm{aB}}$ & $1.63 \pm 0.11^{\mathrm{cB}}$ & $5.17 \pm 0.09^{\mathrm{dA}}$ & $16.42 \pm 0.35^{\text {ев }}$ \\
\hline & & DI & nd & $3.67 \pm 0.18^{\mathrm{bC}}$ & $0.39 \pm 0.02^{\mathrm{aA}}$ & $3.96 \pm 0.30^{\mathrm{bC}}$ & $8.17 \pm 0.15^{\mathrm{cB}}$ & $18.89 \pm 0.28^{\mathrm{dC}}$ \\
\hline & & SDI & nd & $0.08 \pm 0.02^{\mathrm{aA}}$ & $1.41 \pm 0.14^{\mathrm{cC}}$ & $1.37 \pm 0.16^{\mathrm{cA}}$ & No data & $1.18 \pm 0.08^{\mathrm{bA}}$ \\
\hline & \multirow{3}{*}{ Bound } & FI & nd & $10.49 \pm 0.37^{\mathrm{eC}}$ & $4.42 \pm 0.30^{\mathrm{cB}}$ & $1.71 \pm 0.39^{\mathrm{aA}}$ & $3.09 \pm 0.03^{\mathrm{bB}}$ & $9.04 \pm 0.35^{\mathrm{dB}}$ \\
\hline & & DI & nd & $9.62 \pm 0.49^{\mathrm{bB}}$ & $15.66 \pm 0.44^{\mathrm{cC}}$ & $19.62 \pm 0.93 \mathrm{dC}$ & $1.29 \pm 0.06^{\mathrm{aA}}$ & $9.85 \pm 0.43^{\mathrm{bC}}$ \\
\hline & & SDI & nd & $2.53 \pm 0.13^{\mathrm{bA}}$ & $3.85 \pm 0.24^{\mathrm{cA}}$ & $9.70 \pm 1.74 \mathrm{~dB}$ & No data & $1.26 \pm 0.10^{\mathrm{aA}}$ \\
\hline & \multirow{2}{*}{ Total } & FI & nd & $11.51 \pm 0.48^{\mathrm{dB}}$ & $5.22 \pm 0.46^{\mathrm{bA}}$ & $3.34 \pm 0.28^{\mathrm{aA}}$ & $8.25 \pm 0.13^{\mathrm{cA}}$ & $25.26 \pm 0.86^{\mathrm{eB}}$ \\
\hline & & DI & nd & $13.28 \pm 0.31^{\mathrm{bC}}$ & $16.05 \pm 0.41^{\mathrm{cB}}$ & $23.57 \pm 1.23^{\mathrm{dC}}$ & $9.47 \pm 0.08^{\mathrm{aB}}$ & $28.95 \pm 0.88^{\mathrm{eC}}$ \\
\hline
\end{tabular}




\begin{tabular}{|c|c|c|c|c|c|c|c|c|}
\hline & & SDI & nd & $2.61 \pm 0.11^{\mathrm{aA}}$ & $5.19 \pm 0.24^{\mathrm{bA}}$ & $11.07 \pm 1.89^{\mathrm{cB}}$ & No data & $2.49 \pm 0.21^{\mathrm{aA}}$ \\
\hline \multicolumn{9}{|c|}{ Flavones } \\
\hline \multirow{6}{*}{ 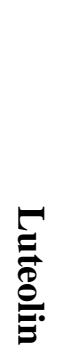 } & \multirow{3}{*}{ Free } & FI & $0.38 \pm 0.06^{\mathrm{aA}}$ & $3.48 \pm 0.10^{\mathrm{cA}}$ & $1.98 \pm 0.08^{\mathrm{bA}}$ & $8.20 \pm 0.04 \mathrm{~dB}$ & $15.11 \pm 0.03^{\mathrm{eA}}$ & $12.59 \pm 0.54^{\mathrm{eB}}$ \\
\hline & & DI & $0.74 \pm 0.13 \mathrm{aC}$ & $6.62 \pm 0.04^{\mathrm{cC}}$ & $3.37 \pm 0.16^{\mathrm{bB}}$ & $10.79 \pm 0.13 \mathrm{dC}$ & $19.14 \pm 0.09$ ев & $19.74 \pm 1.23^{\mathrm{eC}}$ \\
\hline & & SDI & $0.67 \pm 0.04$ aв & $4.08 \pm 0.02^{\mathrm{cB}}$ & $1.94 \pm 0.13^{\mathrm{bA}}$ & $7.33 \pm 0.08^{\mathrm{eA}}$ & No data & $5.59 \pm 0.08 \mathrm{dA}$ \\
\hline & \multirow{3}{*}{ Bound } & FI & $1.72 \pm 0.08$ bB & $3.58 \pm 0.30^{\text {св }}$ & $0.38 \pm 0.02^{\mathrm{aA}}$ & $0.40 \pm 0.08^{\mathrm{aA}}$ & $4.13 \pm 0.13^{\mathrm{dA}}$ & $3.23 \pm 0.23^{\mathrm{cB}}$ \\
\hline & & DI & $3.83 \pm 0.22^{\mathrm{cC}}$ & $5.53 \pm 0.09^{\mathrm{eC}}$ & $0.55 \pm 0.01 \mathrm{aB}$ & $1.35 \pm 0.13^{\mathrm{bC}}$ & $3.61 \pm 0.09$ св & $4.37 \pm 0.25^{\mathrm{dC}}$ \\
\hline & & SDI & $1.41 \pm 0.12^{\mathrm{cA}}$ & $1.71 \pm 0.19^{\mathrm{cA}}$ & $0.86 \pm 0.12^{\mathrm{aC}}$ & $1.09 \pm 0.06^{\mathrm{bB}}$ & No dataa & $1.49 \pm 0.32^{\mathrm{cA}}$ \\
\hline \multirow{12}{*}{ 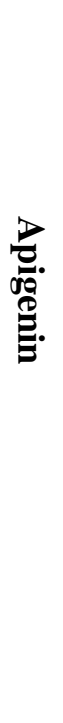 } & \multirow{3}{*}{ Total } & FI & $2.10 \pm 0.02^{\mathrm{aA}}$ & $6.06 \pm 0.40^{\mathrm{cB}}$ & $2.33 \pm 0.12^{\mathrm{bA}}$ & $8.60 \pm 0.13^{\mathrm{dA}}$ & $19.24 \pm 0.10^{\mathrm{eA}}$ & $15.82 \pm 0.30^{\mathrm{eB}}$ \\
\hline & & DI & $4.57 \pm 0.35^{\text {вв }}$ & $12.15 \pm 0.13^{\mathrm{cC}}$ & $3.92 \pm 0.18 \mathrm{aC}$ & $12.14 \pm 0.26^{\mathrm{cB}}$ & $22.75 \pm 0.17^{\mathrm{dB}}$ & $24.11 \pm 0.98^{\mathrm{eC}}$ \\
\hline & & SDI & $2.07 \pm 0.16^{\mathrm{aA}}$ & $5.78 \pm 0.17^{\mathrm{cA}}$ & $2.79 \pm 0.01^{\text {bВ }}$ & $8.42 \pm 0.14^{\mathrm{eA}}$ & No data & $7.07 \pm 0.40^{\mathrm{dA}}$ \\
\hline & \multirow{3}{*}{ Free } & FI & nd & $2.16 \pm 0.24^{\mathrm{bA}}$ & nd & $2.28 \pm 0.26^{\mathrm{bA}}$ & $4.59 \pm 0.11^{\mathrm{cA}}$ & $0.98 \pm 0.35^{\mathrm{aA}}$ \\
\hline & & DI & nd & $4.97 \pm 0.35^{\text {ьв }}$ & nd & $6.04 \pm 0.54^{\mathrm{cC}}$ & $6.70 \pm 0.19 \mathrm{~dB}$ & $1.94 \pm 0.39 \mathrm{aB}$ \\
\hline & & SDI & nd & $2.10 \pm 0.31^{\mathrm{bA}}$ & nd & $4.61 \pm 0.17^{\mathrm{cB}}$ & No data & $0.92 \pm 0.13^{\mathrm{aA}}$ \\
\hline & \multirow{3}{*}{ Bound } & FI & nd & $8.97 \pm 0.08^{\mathrm{dB}}$ & nd & $3.39 \pm 0.24^{\mathrm{bA}}$ & $7.48 \pm 0.22^{\mathrm{cA}}$ & $1.83 \pm 0.51^{\mathrm{aC}}$ \\
\hline & & DI & nd & $23.14 \pm 1.34 \mathrm{dC}$ & nd & $5.71 \pm 0.46^{\mathrm{bC}}$ & $13.60 \pm 0.37 \mathrm{cB}$ & $1.08 \pm 0.40^{\mathrm{aB}}$ \\
\hline & & SDI & nd & $7.05 \pm 0.35^{\mathrm{cA}}$ & nd & $4.03 \pm 0.08^{\mathrm{bB}}$ & No data & $0.91 \pm 0.36^{\mathrm{aA}}$ \\
\hline & \multirow{3}{*}{ Total } & FI & nd & $11.13 \pm 0.32^{\mathrm{cB}}$ & nd & $5.67 \pm 0.02^{\mathrm{bA}}$ & $12.07 \pm 0.33^{\mathrm{cA}}$ & $2.81 \pm 0.88^{\mathrm{aB}}$ \\
\hline & & DI & nd & $28.10 \pm 1.73^{\mathrm{dC}}$ & nd & $11.74 \pm 1.00 \mathrm{bC}$ & $20.30 \pm 0.37$ св & $3.02 \pm 0.78 \mathrm{aC}$ \\
\hline & & SDI & nd & $9.15 \pm 0.04^{\mathrm{cA}}$ & nd & $8.64 \pm 0.05^{\mathrm{bB}}$ & No data & $1.83 \pm 0.49^{\mathrm{aA}}$ \\
\hline
\end{tabular}




\begin{tabular}{|c|c|c|c|c|c|c|c|c|}
\hline \multicolumn{9}{|c|}{ Dihydroflavonol } \\
\hline \multirow{9}{*}{$\begin{array}{l}\overrightarrow{1} \\
\stackrel{0}{\overrightarrow{0}} \\
\overrightarrow{0}\end{array}$} & \multirow{3}{*}{ Free } & FI & nd & $6.93 \pm 0.08^{\mathrm{bB}}$ & $9.35 \pm 0.24 \mathrm{dC}$ & $5.43 \pm 0.06^{\mathrm{aA}}$ & $8.19 \pm 0.30^{\mathrm{cA}}$ & $14.56 \pm 0.34^{\mathrm{eB}}$ \\
\hline & & DI & nd & $11.47 \pm 0.31^{\mathrm{bC}}$ & $8.20 \pm 0.21 \mathrm{aB}$ & $28.64 \pm 1.03^{\mathrm{eC}}$ & $14.93 \pm 0.27$ св & $16.02 \pm 0.57^{\mathrm{dC}}$ \\
\hline & & SDI & nd & $0.31 \pm 0.04^{\mathrm{aA}}$ & $3.01 \pm 0.11^{\mathrm{bA}}$ & $11.18 \pm 0.36^{\mathrm{dB}}$ & No data & $8.86 \pm 0.25^{\mathrm{cA}}$ \\
\hline & \multirow{3}{*}{ Bound } & FI & nd & $2.41 \pm 0.40^{\mathrm{aA}}$ & $6.12 \pm 0.14^{\mathrm{dA}}$ & $4.53 \pm 0.47^{\mathrm{bA}}$ & $5.11 \pm 0.29^{\mathrm{cA}}$ & $10.92 \pm 1.14^{\mathrm{eB}}$ \\
\hline & & DI & nd & $9.58 \pm 0.69 \mathrm{aC}$ & $9.73 \pm 0.20 \mathrm{aC}$ & $12.33 \pm 1.34^{\mathrm{bC}}$ & $16.48 \pm 0.29^{\mathrm{cB}}$ & $18.50 \pm 0.30^{\mathrm{dC}}$ \\
\hline & & SDI & nd & $6.53 \pm 0.13^{\text {bВ }}$ & $8.51 \pm 0.54^{\mathrm{cB}}$ & $10.24 \pm 0.59^{\mathrm{bB}}$ & No data & $4.67 \pm 0.43^{\mathrm{aA}}$ \\
\hline & \multirow{3}{*}{ Total } & FI & nd & $9.34 \pm 0.32^{\mathrm{aB}}$ & $15.50 \pm 0.13^{\mathrm{cB}}$ & $9.96 \pm 0.53^{\mathrm{aA}}$ & $13.30 \pm 0.56^{\mathrm{bA}}$ & $25.48 \pm 0.82^{\mathrm{dB}}$ \\
\hline & & DI & nd & $21.05 \pm 1.00^{\mathrm{bC}}$ & $17.93 \pm 0.01 \mathrm{aC}$ & $40.97 \pm 2.34 \mathrm{dC}$ & $31.41 \pm 0.02^{\mathrm{cB}}$ & $34.52 \pm 0.26^{\mathrm{cC}}$ \\
\hline & & SDI & nd & $6.83 \pm 0.17^{\mathrm{aA}}$ & $11.34 \pm 0.80^{\mathrm{bA}}$ & $21.41 \pm 0.23^{\mathrm{dB}}$ & No data & $13.53 \pm 0.67^{\mathrm{cA}}$ \\
\hline \multicolumn{9}{|c|}{ Flavanone } \\
\hline \multirow{9}{*}{ 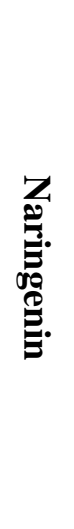 } & \multirow{3}{*}{ Free } & FI & nd & $1.70 \pm 0.06^{\mathrm{aB}}$ & $15.66 \pm 0.05^{\mathrm{dA}}$ & $5.80 \pm 0.42^{\mathrm{bA}}$ & $11.32 \pm 0.44^{\mathrm{cA}}$ & $23.39 \pm 0.80^{\mathrm{eB}}$ \\
\hline & & DI & nd & $2.92 \pm 0.07 \mathrm{aC}$ & $31.88 \pm 0.11^{\mathrm{eC}}$ & $12.47 \pm 0.31^{\mathrm{bC}}$ & $13.19 \pm 0.13^{\mathrm{cB}}$ & $30.60 \pm 2.23 \mathrm{dC}$ \\
\hline & & SDI & nd & $1.15 \pm 0.05^{\mathrm{aA}}$ & $22.51 \pm 0.07^{\mathrm{dB}}$ & $7.69 \pm 0.87^{\mathrm{bB}}$ & No data & $17.63 \pm 1.55^{\mathrm{cA}}$ \\
\hline & \multirow{3}{*}{ Bound } & FI & nd & $3.48 \pm 0.25 \mathrm{aB}$ & $5.54 \pm 0.19^{\mathrm{bA}}$ & $6.11 \pm 0.28^{\mathrm{cB}}$ & $8.04 \pm 0.10^{\mathrm{dA}}$ & $16.64 \pm 1.18^{\mathrm{eB}}$ \\
\hline & & DI & nd & $4.07 \pm 0.22 \mathrm{aC}$ & $8.88 \pm 0.23{ }^{\mathrm{bC}}$ & $9.09 \pm 0.31^{\mathrm{cC}}$ & $10.47 \pm 0.21 \mathrm{~dB}$ & $17.87 \pm 0.43^{\mathrm{eC}}$ \\
\hline & & SDI & nd & $2.74 \pm 0.07^{\mathrm{aA}}$ & $6.96 \pm 0.15^{\mathrm{cB}}$ & $4.58 \pm 0.45^{\mathrm{bA}}$ & No data & $12.50 \pm 2.11^{\mathrm{dA}}$ \\
\hline & \multirow{3}{*}{ Total } & FI & nd & $5.18 \pm 0.19^{a B}$ & $21.14 \pm 0.29^{\mathrm{cA}}$ & $11.91 \pm 0.46^{\mathrm{bA}}$ & $19.36 \pm 1.13^{\mathrm{cA}}$ & $40.02 \pm 1.62^{\mathrm{dB}}$ \\
\hline & & DI & nd & $6.99 \pm 0.27 \mathrm{aC}$ & $40.76 \pm 0.31 \mathrm{dC}$ & $21.56 \pm 0.72^{\mathrm{bB}}$ & $23.65 \pm 0.07 \mathrm{cB}$ & $48.46 \pm 2.66^{\mathrm{eC}}$ \\
\hline & & SDI & nd & $3.89 \pm 0.12 \mathrm{aA}$ & $29.49 \pm 0.10^{\mathrm{cB}}$ & $12.27 \pm 0.66^{\mathrm{bA}}$ & No data & $30.13 \pm 1.86^{\mathrm{cA}}$ \\
\hline
\end{tabular}

${ }^{\text {a-e }}$ Values with different superscripts in the same row are significantly different $(p \leq 0.05)$. ${ }^{\text {A, B, C }}$ Values with different superscripts in the same column in the same dependent variable are significantly different $(p \leq 0.05) . \mathrm{nd}=$ not detected. 

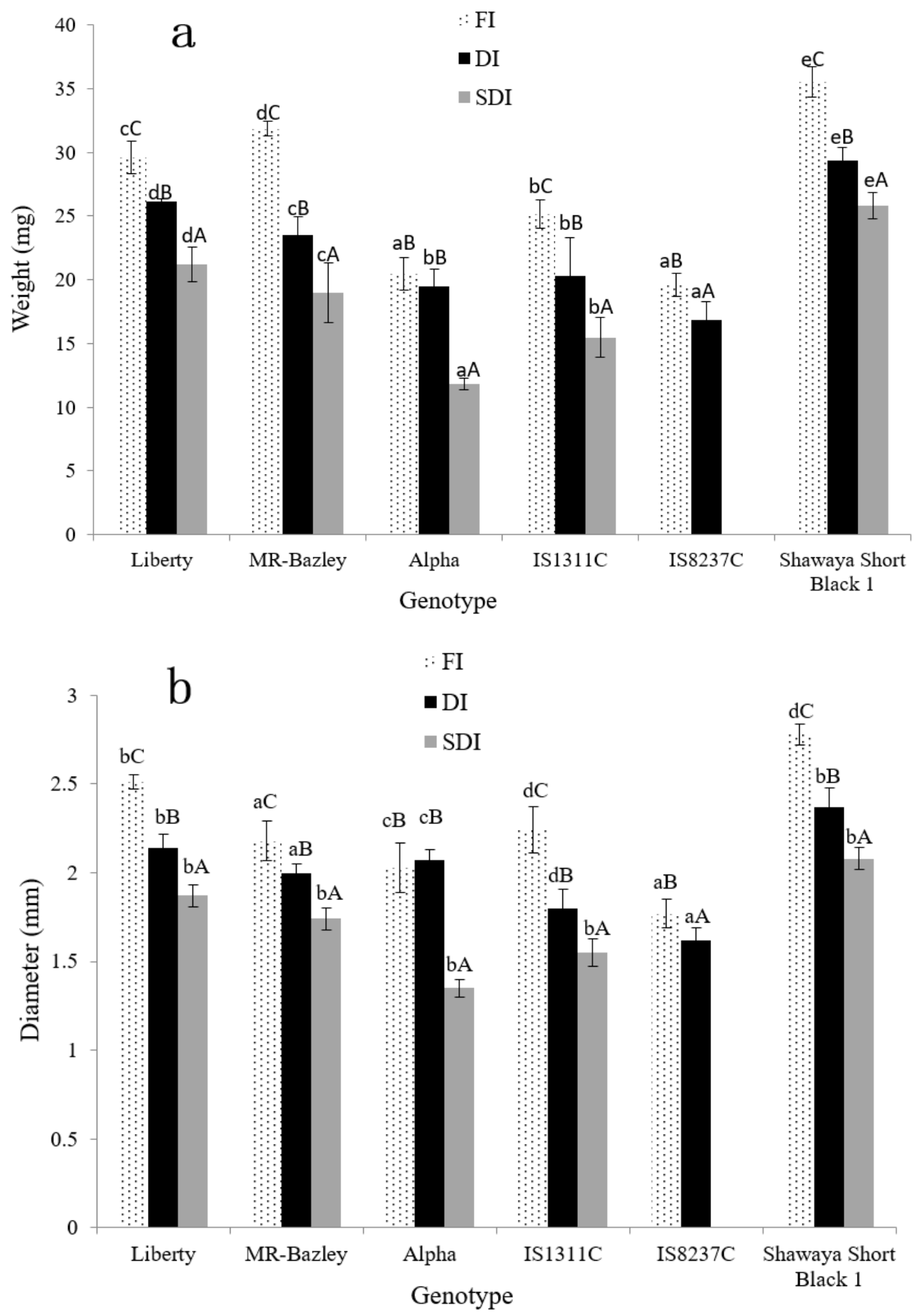

Figure 1 


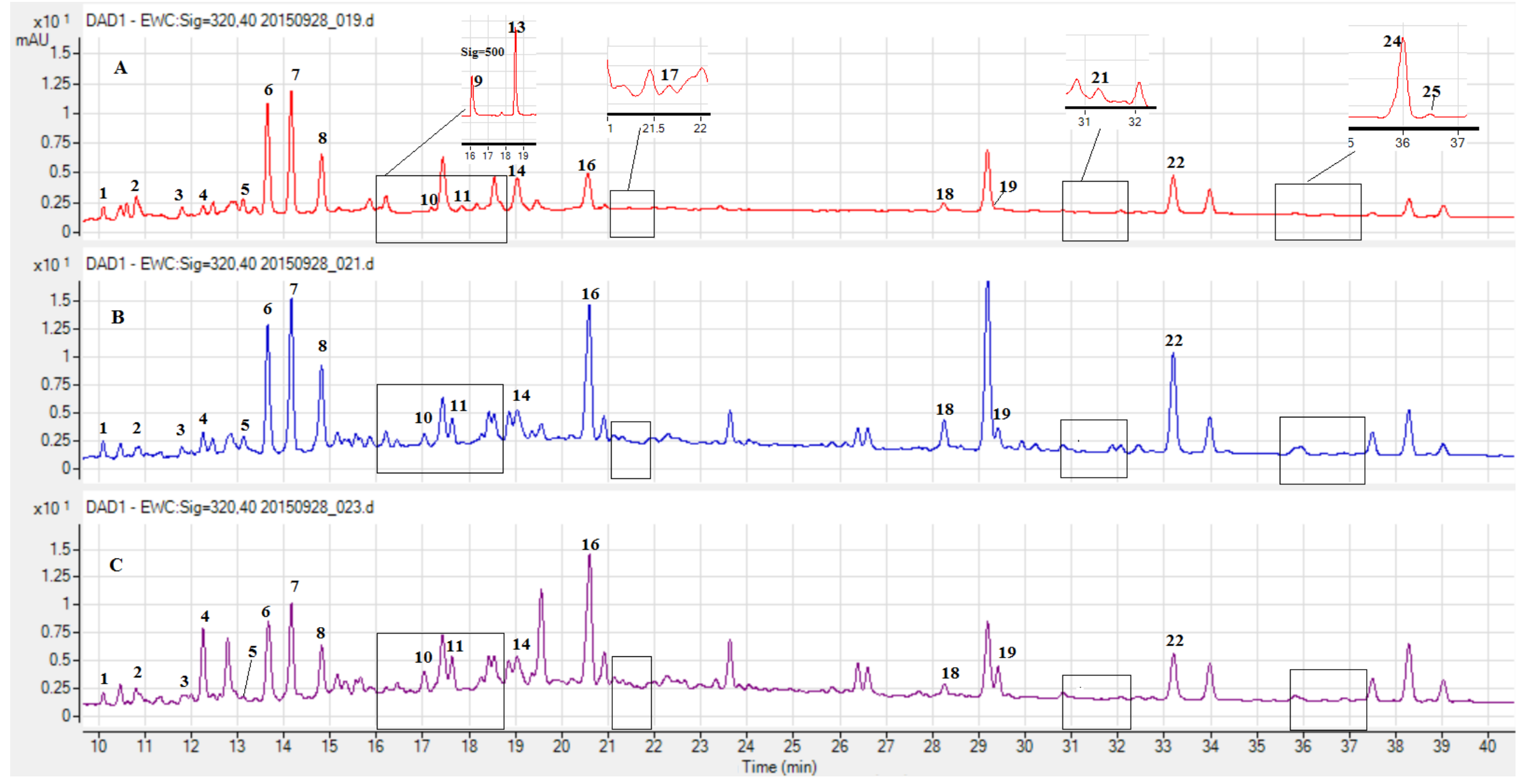

Figure 2 

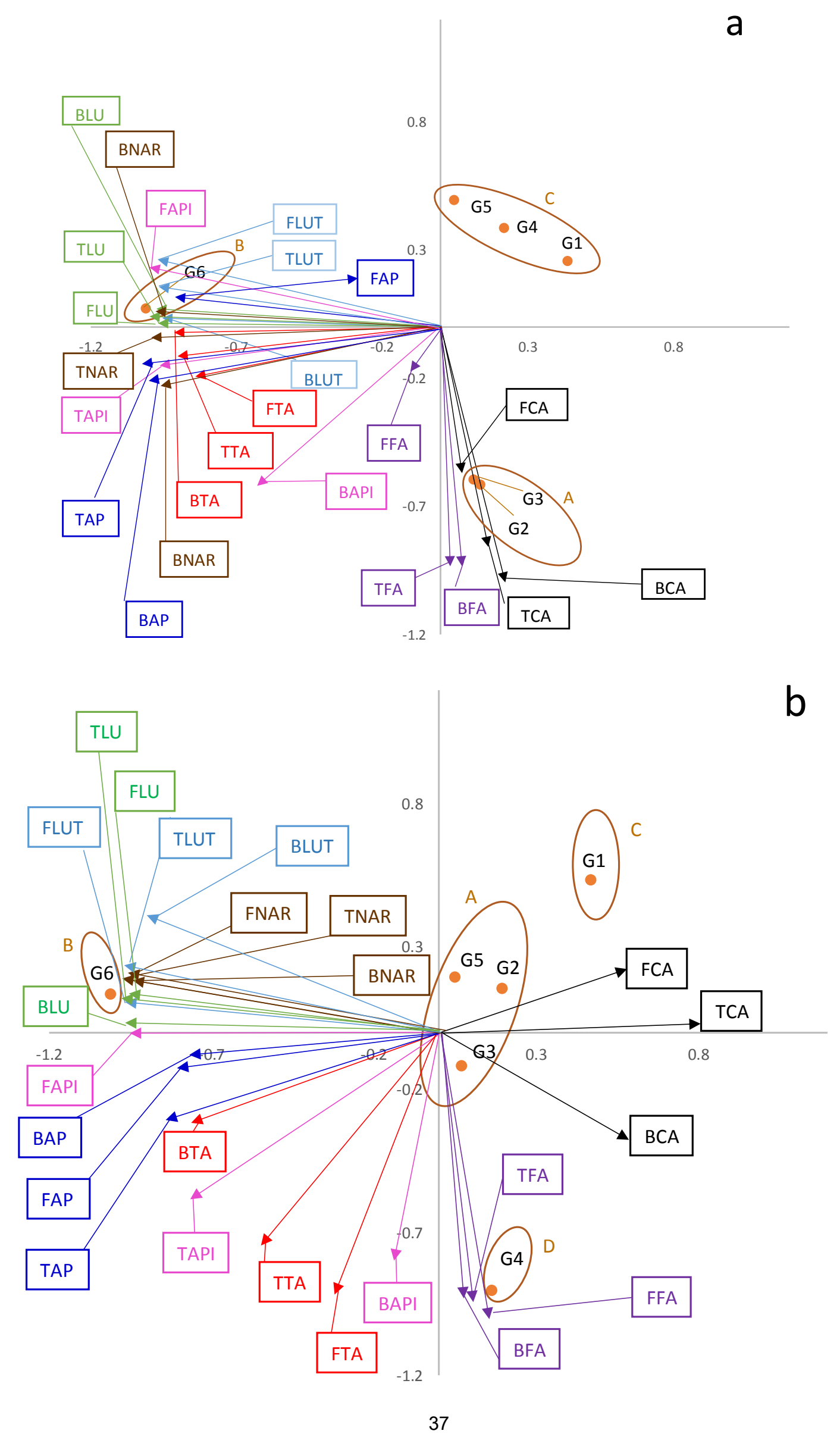


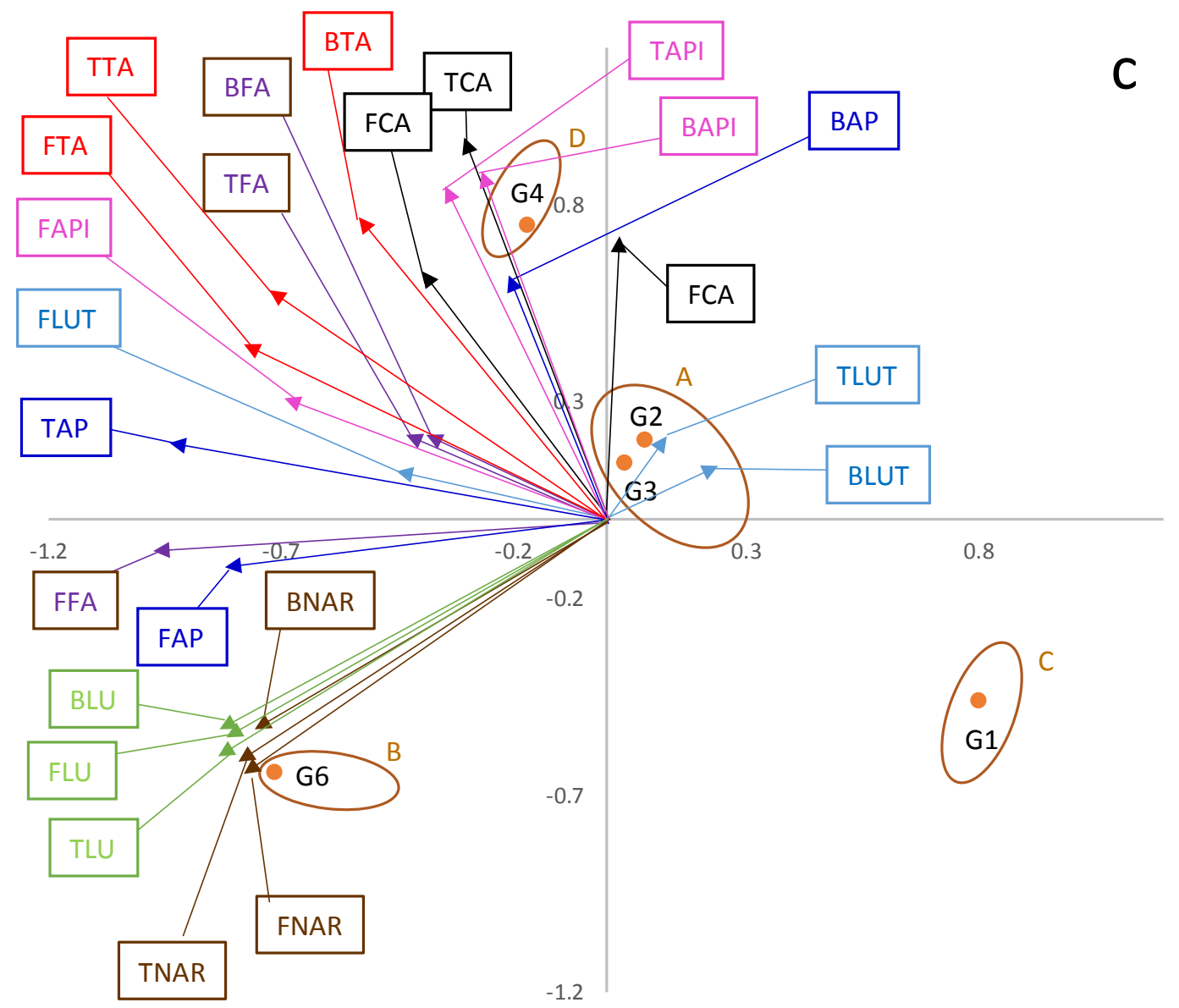

Figure 3 